\title{
TRANSTEMPOS DE “NENÉM”: PROCESSO DE RURBANIZAÇÃO EM COMUNIDADE REMANESCENTE DE QUILOMBO
}

\author{
Caroline do Socorro Silvestre Oliveira ${ }^{1}$ \\ Daniel dos Santos Fernandes ${ }^{2}$
}

\section{LUGAR E GESTAÇÃO}

Coletamos e analisamos histórias de vida da moradora Osmarina (conhecida como dona Neném) da Comunidade Remanescente de Quilombo de Nossa Senhora do Livramento, localizada no município de Igarapé-Açu, nordeste paraense, de modo, a partir das narrativas orais, verificar como a memória se processa no seio dessa comunidade, uma vez que, a memória do passado pode ser representada no "agora" da comunidade, como um recorte do tempo atual.

Assim sendo, desenvolvemos a presente pesquisa nessa comunidade a partir de uma relação entre pesquisador e sujeito da comunidade, onde optamos por um trabalho de natureza interdisciplinar, história oral, narratologia e etnografia com embasamento teórico de intelectuais como Walter Benjamin (1994), Ecléa Bosi (1994), Henri Bergson (1959), Halbwachs (1968), Bauman (2005), Stuart Hall (2011), Freire (1982), entre outros, de maneira a penetrar nas histórias de vida da comunidade, a fim de conhecer suas trajetórias de luta e de organização, inscritas a partir da memória de dona Neném, a pessoa mais velha da comunidade. Optamos por não legendar as imagens, autorais, por acreditar que a imagem é um texto que dialoga em paridade, bem como as falas da narradora, que estão dentro do texto apenas em fonte diferente, por acreditarmos que o texto tem que dar visibilidade equânime a todos que o construíram.

Ao coletarmos e analisarmos as narrativas das histórias de vida da moradora mais antiga da comunidade, registrando fatos e informações acerca dos aspectos

\footnotetext{
${ }^{1}$ Secretaria Estadual de Educação do Amazonas, Brasil. Email: caroline.oliveira@seducam.pro.br ORCID id: https://orcid.org/0000-0003-4240-5228

${ }^{2}$ Universidade Federal do Pará, Brasil. Email: dsfernandes@ufpa.br

ORCID id: https://orcid.org/0000-0001-8450-8060
} 
sociais, históricos e culturais da comunidade, visando compreender como se dá o processo de rurbanização da comunidade, o que vem se processando nas comunidades tradicionais próximas a centros urbanos, por meio das lembranças que estão armazenadas na memória da narradora. Recuperar a sua memória social, como guardiã de informações desse lugar em que os jovens não viveram, aponta para a necessidade de valorização da transmissão oral, em uma construção de passado e presente.

Segundo Baumam (2003), as palavras são carregadas de significados, e algumas delas, sensações que não são independentes, claro. São sensações que nem sempre estão ao alcance, pois, as comunidades, nos dias de hoje, são "o paraíso perdido ou paraíso esperado". Imaginada ou de realidade, o importante é ser de uma comunidade e buscar caminhos para se chegar ao "paraíso". Logo, viver em comunidade é ter "direito" de ter "a identidade", pois, "comunidades são entidades que definem as identidades".

\begin{abstract}
No livro que (intencionalmente ou não) convidava a "comunidade"(Gemeins chaft) a voltar do exílio a que tinha sido condenada durante a cruzada moderna contra lês pouvoirs intermédiaires (acusados de paroquialismo, estreiteza de horizontes e fomento à superstição) Ferdinand Tönnies sugere que o que distinguia a comunidade antiga da (moderna) sociedade em ascensão (Gesellschaft) em cujo nome a cruzada fora feita, era um entendimento compartilhado por todos os seus membros. Não um consenso. Vejam bem, o entendimento ao estilo comunitário, casual (zuhanden, como diria Martin Heidegger), não precisa ser procurado, e muito menos construído: esse entendimento já "está lá", completo e pronto para ser usado - de tal modo que nos entendemos "sem palavras" e nunca precisamos perguntar, com apreensão, "o que você quer dizer?". O tipo de entendimento em que a comunidade se baseia precede todos os acordos e desacordos. Tal entendimento não é uma linha de chegada, mas o ponto de partida de toda união. É um "sentimento recíproco e vinculante" (Bauman, 2005: 16).
\end{abstract}

Neste sentido, a comunidade pode representar um abrigo em relação aos efeitos da globalização. No caso das comunidades quilombolas é uma questão a ser observada, pois, "são grupos que possuem culturas diferentes da cultura predominante na sociedade e se reconhecem como tal. Esses grupos devem se organizar de forma distinta, ocupar e usar territórios e recursos naturais para manter sua cultura" (Brasil, 2007: 1).

Apesar da prática do quilombo se expandir por todo território brasileiro, "multiplicando sua face, criando uma diversidade de possibilidade e especificidade, essa multiplicidade dificulta uma caracterização única e fechada do que seja o quilombo" (Amaral, 2014: 94); essas comunidades negras ainda hoje (em pleno 
século XXI) são deixadas de lado pelo poder público. Muitas, predominantemente rurais, já se encontram em espaços limítrofes com o urbano. Antes viviam isoladas e não precisavam resistir às pressões de especuladores imobiliários, latifundiários e até mesmo do poder público pela manutenção ou reconquista de seus territórios.

O poder público em suas esferas de posicionamentos "sociais' direcionam suas políticas públicas com matizes a novas tendências a complementariedade entre rural/urbano, um tipo de meta equivocada no caso das comunidades quilombolas, construindo saídas definitivas, como o ressarcimento de dívidas históricas, que possibilita uma vida a curto e médio prazo, um dia-a-dia melhor e de relações sociais mais complexas, a exemplo de Gilberto Freyre (1982), ao apontar o sinal mutilador afirmado pela escravidão.

Contatos entre o rural e o urbano, processo de rurbanização, não é novidade. Gilberto Freyre já ventilava pensamentos de desenvolvimento integrado, como rurbanização, em suas ideias sociais em Casa Grande \& Senzala, trabalho onde constrói seu pensamento de um Brasil que seria encaixamento de vários antagonismos que, coexistindo, concorreriam para uma cultura criativa, onde o primitivo se une a ações racionalizantes, dando origem aos espaços rurbanizados.

Deste modo, o processo de territorialização quilombola constitui-se na maioria das vezes, na luta para continuar a existir, ou seja, na reinvenção de uma identidade política portadora de direitos. Portanto, neste artigo, procurou-se costurar a(s) memória(s) de dona Osmarina, por meio de suas lembranças, para compreendermos como este processo de rurbanização está se processando e suas possíveis interpretações.

\section{CONSTRUÇÕES E NASCIMENTOS}

Segundo o estudo A formação territorial do espaço paraense: dos fortes à criação de municípios (2008), a antiga estrada de ferro Belém-Bragança teve sua construção iniciada em 1875 e concluída no ano de 1908, com objetivo de colonizar a área Belém-Bragança e abastecer Belém com produtos agrícolas. Decorrente disso chegaram os migrantes, sobretudo nordestinos, fazendo surgir os povoados, as vilas, que hoje são municípios, como no caso, Igarapé-Açu, Nova Timboteua, entre outros. 
O acesso a esses municípios se dá por via terrestre: partindo-se da capital Belém, toma-se a BR - 316 até Castanhal, e a partir desse ponto segue-se pela Rodovia PA-320 até a sede do município de Igarapé-Açu, chegando à Rodovia Estadual PA-242. Entre Igarapé Açu e Nova Timboteua fica localizada a comunidade da pesquisa, na via da antiga estrada de ferro que ligou Belém à Bragança até o ano de 1964, da qual resta hoje apenas a ponte de ferro sobre o rio Maracanã.

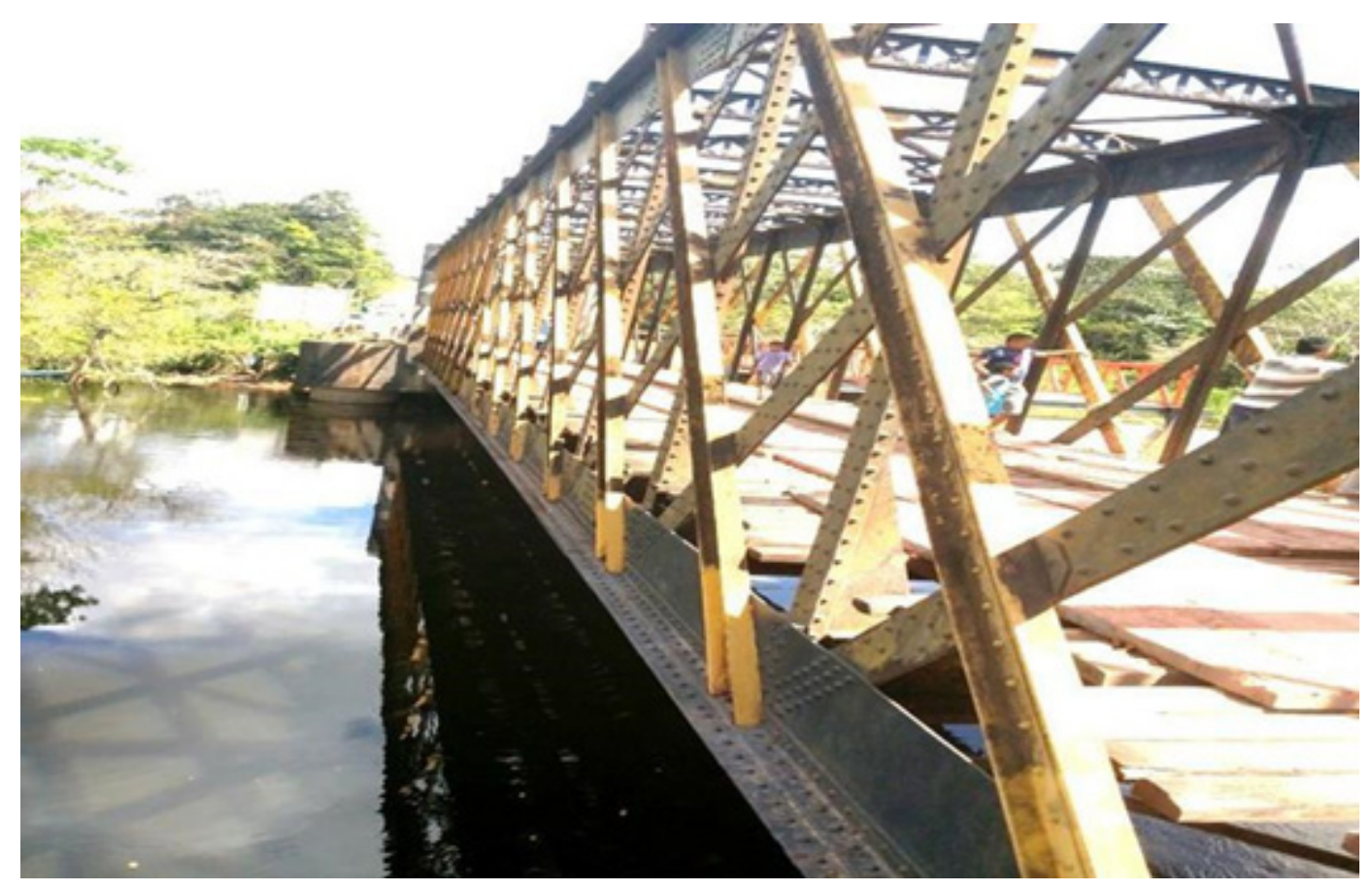

Mesmo diante da informação de que a comunidade foi refúgio de negros escravos, somente em junho de 2010 a comunidade recebeu o título de reconhecimento de quilombo, publicado em 13 de novembro do ano de 2009 no Diário Oficial do Estado do Pará, precisando retornar ao Instituto de Terras do Pará ITERPA para ser arrecadada e matriculada, e posteriormente, o título definitivo ser registrado em cartório imobiliário em nome da comunidade.

Nessa, atualmente, residem cerca de 55 famílias, que trabalham na agricultura familiar, pesca e extração de junco. As roças em sua maioria são de mandioca para a produção da farinha e trabalhadas no espaço familiar. 


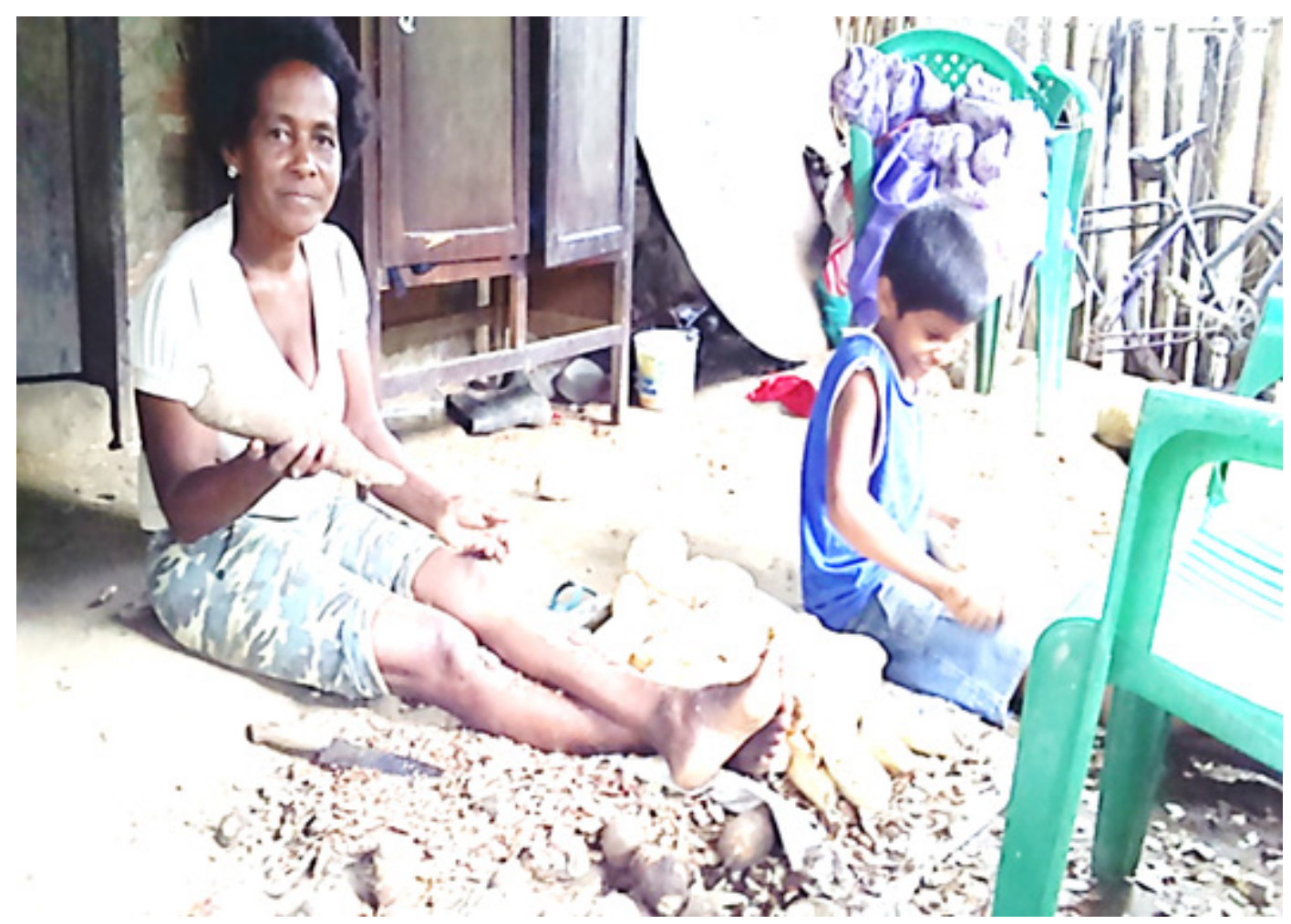

Na área de várzea é extraído o junco, que depois de seco é usado na fabricação de esteiras para cangalha de animal, vendidas em feixes para outros municípios.

$\mathrm{Na}$ localidade há uma Escola Municipal de Ensino Fundamental. Após concluírem esse período escolar, os alunos passam a estudar na Vila São Luís (Rodovia Estadual PA - 242 - Igarapé-Açu - PA) para dar continuidade aos estudos. A comunidade possui uma igreja católica (Igreja de Nossa Senhora do Livramento) e dois pequenos estabelecimentos comerciais. Possui luz elétrica e água encanada. As casas, hoje, em sua maioria são de alvenaria (construídas com tijolos) e cobertas com telhas de barro. Poucas são aquelas de taipa (barro).

É neste panorama espacial que Dona Osmarina, moradora mais velha da comunidade, e autora das narrativas deste artigo. A mesma explica que o nome da comunidade, Nossa Senhora do Livramento, segundo seus antepassados, foi escolhido porque a área serviu de refúgio para os escravos vindos do Maranhão, quando esses se refugiaram às margens do rio.

Osmarina Silva do Nascimento nasceu em 05 de abril de 1932 na Comunidade Remanescente de Quilombo Nossa Senhora do Livramento - PA. Filha de Simão Eduardo Martins e Florentina Goulart da Silva. Por conta de uma infância em 
deslocamento geográfico teve apenas escolarização básica, sabendo somente assinar seu nome.

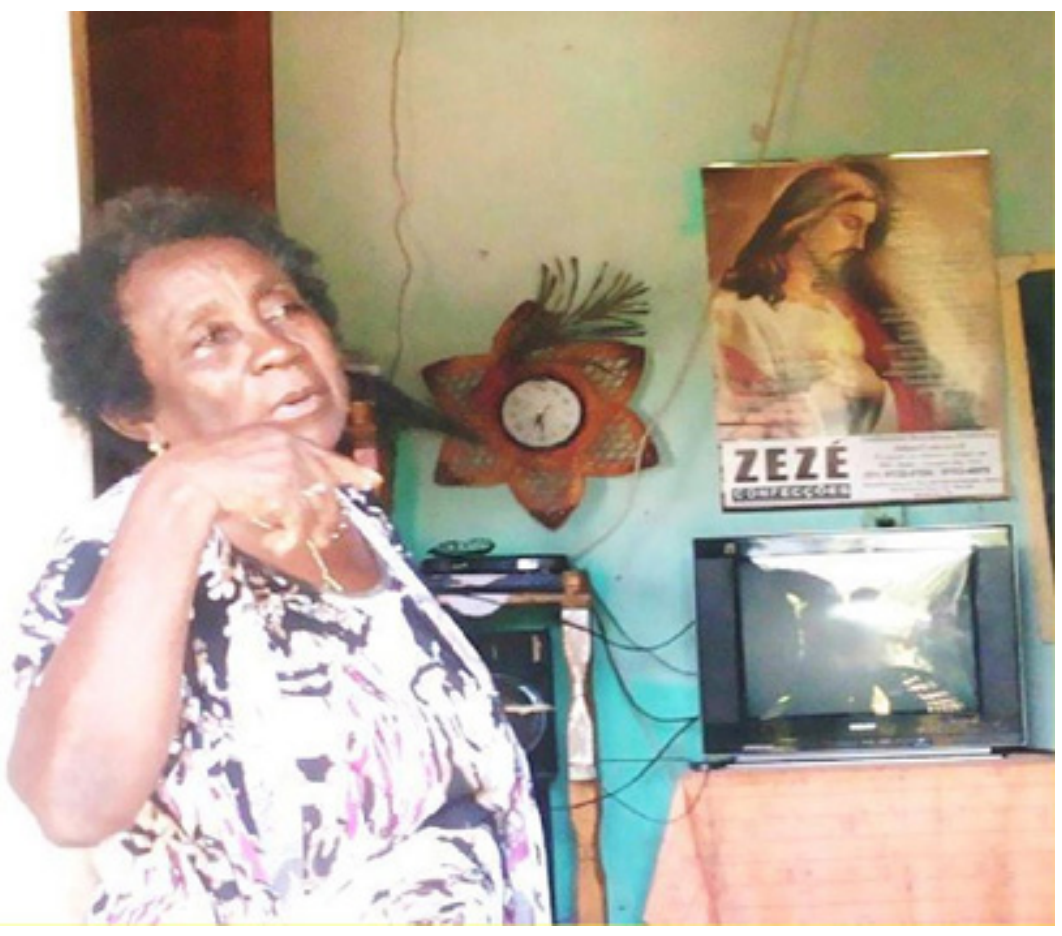

De acordo com Halbswachs, o idoso desempenha um papel fundamental na sociedade, "uma espécie singular de obrigação social, que não pesa sobre os homens de outras idades: a obrigação de lembrar, e lembrar bem" (apud, Bosi, 1994, p 63). Percebe-se assim que a pessoa idosa possui uma função ímpar na sociedade, a de lembrar, ou melhor, é ela responsável pelo maior bem de uma sociedade: a memória.

Para Bosi (1994, p 82), “o ancião não sonha quando rememora: desempenha uma função para a qual está maduro, a (...) função de unir o começo ao fim, (...)”. Assim, partindo das ideias de Bosi, percorremos por meio das lembranças de Dona Osmarina, as histórias não somente dela, mas as histórias e memórias da "Comunidade remanescente de quilombo Nossa Senhora do Livramento", haja vista que as histórias narradas por ela se misturam com a história da referida comunidade.

Dona Osmarina (Neném) inicia o relato de sua vida falando de sua origem, da origem de sua família (de seus pais). Esse relato é baseado nas lembranças que estão guardadas em sua memória. É interessante que, para isso, ela retrocede no tempo, um tempo que não foi vivido por ela, mas por seus pais.

Para explicar a situação acima, recorremos a Halbwachs (2003), pois esse solicita que observemos a memória individual, já que essa "não está inteiramente 
isolada e fechada", ou seja, para "evocar seu próprio passado, em geral a pessoa precisa recorrer às lembranças de outras, e se transportar a pontos de referência que existem fora de si, (...)" (Halbwachs, 2003: 72)

A narradora nos conta a história de seu pai e de seus avós; descreve que a família de seu pai era do Maranhão; era uma família numerosa, composta de 12 filhos, porém nunca lhe faltou nada. Relata-nos também que seus tios moravam no outro lado do rio, ao lado da igreja que existia naquele local, com a imagem de Nossa Senhora do Livramento, que foi trazida por eles, a qual deu o nome à referida comunidade. Tinha essa Santa, então essa Santa vívía com as minha tias do outro lado, não era aqui. Eles trouxeram essa Santa, as minhas tias, meu tio. Aí fizeram uma igreja lá onde elas moravam. Era Nossa senhora do Livramento. Então um dia desses veio um pessoal procurar saber: porque Nossa Senhora do Livramento? Aí elas foi e disse... Porque Nossa Senhora do Livramento, se você fazer promessa com fé, "Ó minha Nossa Senhora, você vai me livrar, vai me ajudar". Quando pensa que não, você recebe essa benção. Então ficou Nossa Senhora do Livramento. Informou-nos ainda que foi nessa igreja que ela e seus irmãos foram batizados. Além disso, seus pais tinham muita fé em Nossa Senhora do Livramento, e de acordo com a narradora, essa devoção foi passada de geração a geração, tanto que hoje a filha de dona Osmarina é a "zeladeira"3 da igreja.

Ao ser indagada sobre seu tempo de adolescente, a narradora nos afirma que era bom porque tinha o arraial. Porque quando é assim eles não andavam assim que nem agora, tirando donativo, aú faziam o mesmo arraial. Esse pessoal que queria ser o dono, esse pessoal, a Lorença, ela dizia que a igreja era dela, aí não quería que ninguém, negócio de preto, entrar na igreja dela. Aí a Tereza foí em Igarapé -Açu e fatou com o padre.

\footnotetext{
${ }^{3}$ Pessoa responsável por limpar determinado local, nesse caso, a igreja de Nossa Senhora do Livramento.
} 
o padre Calado que é lá de Igarapé Aç. Á́ foì e mandou dizer pra ela que ela deixasse a gente tomar conta da igreja, porque se não quem vinha aqui pra resolver com ela era ele. Porque a igreja era do pessoal não era dela (pausa). Á ela liberow a igreja. Ainda disse que lá não ía deixar preto entrar na igreja. Minha fitha sabe tudo, que ela ainda foi em Igarapé-Aç. A igreja tava toda cheia de mato, toda suja, cobra morta, era rato. Vivia abandonada. Aí ele disse: "pode abrir a porta". Até pé de imbaúba já tinha em cima. Á pronto, ela fícou tomando de conta. Primeiro era eu, aú quando foi chegando uma certa idade aúewentreguei pra ela.

$\mathrm{Na}$ conversa acima a narradora nos relata algumas situações vivenciadas naquele período, sendo importante destacar nesse trecho questões sobre o racismo e o preconceito racial, haja vista que é observado nesse fragmento a discriminação racial por parte de alguns moradores da comunidade. Este fato está nítido na fala de Lorenza, quando diz, "(..) negócio de preto, entrar na igreja dela". Assim, percebe-se que no tocante à situação do negro naquele período, não era diferente de outras regiões, pois o preconceito estava disseminado em toda sociedade brasileira, onde o negro era visto como ser inferior e sem direitos, impedidos de frequentar "os lugares dos brancos". Com relação a essa questão do racismo, Bentes destaca que:

[...] Além dos atos disfarçados e das negações, o racismo também pode estar manifestado nas atitudes, opiniões e estereótipos; nas ideologias; nas relações interpessoais; nas práticas sociais; e nas instituições. [...] O racismo é um instrumento para ganhar e manter o poder.(2014: 56)

É importante destacar na fala da narradora o trecho em que ela se refere à senhora Lorenza, quando essa diz que "lá não ia deixar preto entrar na igreja", ou seja, é alguém de dentro da própria comunidade que não aceita a diferença, que tenta impor uma única identidade. Em relação a isso, Hall (2011: 17) assevera que as sociedades atuais, ou como ele próprio utiliza, as sociedades da modernidade tardia, 
são marcadas pela 'diferença', ou seja, "elas são atravessadas por diferentes divisões e antagonismos sociais que produzem uma variedade de diferentes 'posições de sujeito' - isto é, identidades - para os indivíduos". Deste modo, se pode afirmar que as identidades não obedecem a um modelo fixo, ou seja, elas são marcadas por tensões e negociações, em suma, as identidades são marcadas por diferenças.

É interessante observar ainda que, ao pedirmos para dona Osmarina falar de sua adolescência, os relatos são confusos, pois ela acaba misturando os períodos, ou seja, começa contando fatos da adolescência e em seguida fala de sua fase adulta. Percebe-se, com isso, que essas lembranças estão estilhaçadas pelo tempo. De tal modo, a moradora vai rememorando suas histórias, nos relatando também que anteriormente era ela quem tomava de conta da comunidade, porém, devido à idade avançada, ela passou a tarefa para a filha Tereza.

Dona Osmarina, por meio dessas conversas, nos fornece uma breve história de vida e também da Comunidade Nossa Senhora do Livramento, por meio de suas lembranças (que aos poucos emergem de sua memória, bastante fragmentada). A mesma nos relatou que foi no Hangar em Belém do Pará que os sujeitos sociais que residem na referida comunidade passaram de posseiros a remanescentes quilombolas, conforme nos relata: aú depois fomos pra Belém, pratirar o documento, pra receber o documento. Eu recebi lá em címa, no Hangar, foi... for, for muito bonito. Foi um ônitus cheio. Nós fíquemos lá, num apartamento lá em cima, foi muito bonito" (sorrindo).

De acordo com as ideias acima, as imagens sobre o surgimento da Comunidade de Nossa Senhora do Livramento são reconstruídas pela narradora, base para essa análise. Portanto, será a própria moradora que irá nos relatar como se deu esse processo e para isso, ela utilizará a memória como aliada. Inicia a narrativa: as minhas tias, os meus tios, moravam lá do outro lado do río, onde tinha a outra igreja, eles vieram fugidos... Agora nós procurava saber de onde eles tinham vindo fugido, mas eles não comunicavam a gente, só seí que veio fugido. $O$ meu tio, ai três tias também, vieram tudo de lá (Enríquita, 
Fabiana e Furtunata). Era esses que moravam do outro lado, of mais antigos lembra... Eles falavam que eles eram índios urubus", que muitos morreram por dentro do mato, fugindo, eles contavam..

A maneira com que dona Osmarina narra a história do lugar é admirável, pois ela nos conta ao sabor da memória e com tamanha precisão dos fatos, como alguém que fora ouvinte/testemunha. Para explicar tal situação, buscamos auxílio nas palavras de Bosi (1994), pois, segundo a autora: "um mundo social que possui uma riqueza e uma diversidade que não conhecemos pode chegar-nos pela memória dos velhos. Momentos desse mundo [...] podem ser compreendidos por quem não os viveu $[\ldots] ”($ p. 82).

Mais uma vez fica claro o papel e a importância de uma pessoa mais velha, não somente para a referida comunidade, mas para toda a sociedade, pois como afirma Bosi (1994: 18), os velhos "são a fonte de onde jorra a essência da cultura, ponto onde o passado se conserva e o presente se prepara (...)”. Sobre a comunidade, ela relata,

otha, o mew marido falava da ponte, contava quando "tavam" construindo. Ele disse que teve muitos que morreram (...). Eles "tavam" trabalhando, aí caí uma coisa, ai muitos faleceram. É muito fundo. Aí agora o pessoal tão com medo, porque a ponte nova que fizeram, ela tá rachando. A marévai enchendo, como a maré enche, tá abalando ela. Uma vez caíu, caúu duas vezes quando eles "tavam" trabalhando...

\footnotetext{
${ }^{4}$ Os caapores (também chamados urubus, urubus-caapores, cambôs e ka'apor) são um povo indígena que vive no estado do Maranhão, no Brasil. O seu nome significa "povo da mata", através da junção dos termos tupis ka'a ("mata") e poro ("povo"). [ ...] Este povo surgiu distintamente há cerca de trezentos anos atrás, provavelmente na região entre os rios Tocantins e Xingu. Migraram, em 1870, do Pará, através do Rio Gurupi, para o Maranhão. Essas informações estão disponíveis em: $<$ https://pt.wikipedia.org/wiki/Caapores> Acesso em: 16. 09. 2015. É possível que a família de dona Neném, ou melhor, dos primeiros habitantes da Comunidade Nossa Senhora do Livramento serem de origem afro-indígena, algo bastante comum na região Amazônica. Contudo, neste trabalho não entraremos nessa discussão, haja vista, não ser esse o objetivo desta pesquisa, portanto, essa questão pretende-se aprofundar em estudos futuros.
} 
De acordo com o exposto, a narradora nos conta partes da história da comunidade, tais como: a construção da ponte, dos trabalhadores que nela trabalhavam, dos acidentes ocorridos no local e do medo das pessoas de transitar por ela, ou seja, dona Osmarina se utiliza de elementos espaciais para reconstruir essas imagens. Ou seja, mais uma vez ela recorre a testemunhos, para ajudá-la a reconstruir a memória, como nos é mostrado no fragmento acima, quando se utiliza das memórias de seu marido para reconstruir a história local.

A partir dessas conversas foi observado o importante papel desta mulher na comunidade de Nossa Senhora do Livramento, haja vista que a mesma ajudou a construir a comunidade, além de desempenhar inúmeros papéis (sociais, políticos, econômicos e culturais). Segue um trecho da entrevista onde dona Osmarina expõe a participação de mulheres de sua família na organização da comunidade, a minha mãe era muito virada, quem puxou pra ela é essa Tereza (fitha), virada. Eu fico alegre porque todo mundo procura por ela. Aqui o pessoal fica com raiva dela, porque quando o pessoal chega, procura por ela. Ora, se ela hutou muito. En que hutava pra abrir essa comunidade, for ew...

Dona Osmarina se refere à filha Tereza cheia de orgulho, como se a vida da filha fosse a continuidade da sua. Em princípio, talvez, ela até imagine assim, pois nota-se no fragmento acima a certa incerteza na fala da moradora quando ela diz: “Ora, se ela lutou muito. Eu que lutava [...], foi eu...", gerando assim, uma dúvida: de quem afinal ela está falando? Da filha, ou dela própria? Porém, algo está bastante nítido no fragmento acima: que a referida moradora sente muito orgulho de pertencer a essa família e também de ter contribuído com a história da comunidade. Essa contribuição é evidenciada em vários momentos da conversa, eu que andava pra todo canto, negócio de reunião. Quando Tinha uns candidatos que quando ía pras colónias, quem ía era ew. Aí eles mandavam eu convidar o pessoal da comunidade, nós não tinha nada, nem terra nós não tinha. Nós tava morando, mas era mesmo que ser um posseiro, que não 
tinha documento nenhum. Aí disque que era do governo (pausa). Rapaz, aú quando o governo chegar manda nós sair. Pra onde nós vamos?

Está registrado também no fragmento acima que eles moravam naquela localidade, porém não possuíam documento legal da terra, além do que, estavam sempre com medo de serem expulsos da terra. Uma questão muito importante a destacar nesta pesquisa é a respeito da identificação enquanto quilombola, haja vista que segundo a narradora, (...) de três a quatro anos pra cá que aparecew a senhora de Betém. Aí ela veio informando a Tereza. Aí ela disse: "Otha dona Tereza, eu quero que vocês reinem o pessoal daqui e vão em Belém. Foi descoberto que vocês são quitombolas. Tereza sabe o nome dela (...)

De acordo com a referida moradora, até a chegada dessas pessoas vindas de Belém, eles nunca haviam obtido informações acerca da palavra quilombola. Foram essas pessoas as primeiras a identificá-las como quilombolas. Contudo, é importante destacar ainda o esquecimento de dona Neném em alguns momentos da entrevista, sobretudo, no fato desta não se recordar do nome da "senhora de Belém" que os ajudou no reconhecimento como comunidade quilombola. Essa omissão não nos tira a compreensão do fato narrado. Assim, a referida moradora continua narrando as histórias sobre a comunidade, e assevera, [...] veío um pessoal de Betém, donaKaritene, dona Nazaré... Sógente "grandão", e eles disse: "Otha, vocês vão ser posseiros dessa terra, que vocês", nós já notemos que vocês são os quitombolas". Então, graças aDeus, de direito, né?!

Está evidenciado, portanto, por meio do discurso da narradora, que os moradores da comunidade de Nossa Senhora do Livramento não se identificavam como remanescentes quilombolas, ou seja, foi uma identidade originada por pessoas de fora da comunidade, sendo essa acolhida por trazer benefícios à referida

\footnotetext{
${ }^{5}$ Relativo a prestígio, ou seja, pessoa importante.
} 
localidade. Em relação a isso Teixeira (2014) afirma que: "a formação das identidades quilombolas vincula-se ao pertencimento a uma dada territorialidade".

Acerca de territorialidade, segundo Teixeira (2014), “diz respeito às relações econômicas e culturais, estando intimamente ligada ao modo como as pessoas utilizam a terra, como elas [...] se organizam no espaço e como elas dão significado ao lugar" (p. 248-249). Logo, de acordo com autor, identidade étnica, território e territorialidade são termos que estão relacionados entre si, sendo, portanto, indispensáveis para a compreensão das comunidades negras, sejam elas rurais ou urbanas.

Acerca dos moradores do local, em sua maioria, não terem a compreensão do que significa ser ou pertencer a uma comunidade quilombola, eles percebem que houve mudanças após a titulação da terra, após a denominação como comunidade remanescente de quilombola, como nos é informado por dona Osmarina, tá mudando tudo. Tá mudando porque nós aqui não tinha nada. Como eu te falei, nós era posseiros daqui, nós não tinha nada. Os moradores venderam, venderam, e for ficando só essa parte daqui. Essa parte da fazenda aqui do Japonés, tudo era nosso. O pessoal até quería fazer coisa pra tomar dele, mas eu e a Tereza não aceitemos. "Vai que o Japonés solta uma bomba aqui (risos). Nós queremos só esse pedaco mesmo".

Percebe-se ainda, no discurso da moradora acima, o conformismo da mesma, ao falar da fazenda do Japonês, das terras que antes pertenciam à comunidade e hoje pertencem ao referido senhor. Talvez não seja conformismo, mas sim o medo de perder a terra, ou melhor, de ser expulsa da terra em que nasceu e onde criou seus filhos. Uma das possibilidades com relação a essa questão se dá devido ao desconhecimento dos próprios moradores em relação às leis existentes para "protegêlos", ou que deveriam "proteger".

Essa questão acima é muito recorrente no Brasil, principalmente na Amazônia, onde os conflitos agrários são intensos, pois apesar da imensidão desse país, na hora 
da distribuição de títulos agrários nem todos foram beneficiados, sendo que a terra ficou concentrada nas mãos de poucos. Todavia, os que não conseguiram os referidos títulos, ou seja, os colonos, de acordo com Bentes (2013: 24), esses "foram ocupando áreas mais ao interior, tornando-se posseiros". No período em que as terras foram ocupadas por esses grupos, eram desvalorizadas, diferentemente de hoje, onde há uma grande especulação de terras.

Outro ponto a ser mostrado é sobre o não reconhecimento enquanto quilombola por parte da juventude. Ao perguntarmos sobre essa questão para dona Osmarina, ela imediatamente respondeu que não há esse reconhecimento. Isto é, ela asseverou que atualmente, tanto os netos dela, quanto os outros jovens da comunidade não se reconhecem enquanto quilombolas, ou seja, para eles não há diferença alguma. O que também já assinalava no lado negativo da rurbanidade, o tipo de relação cultural entre campo/cidade (Freyre, 1956, in 1982), o movimento negativo - oposto, grave se não interditado e revertido - de esvaziamento dos melhores valores humanos de que padeciam os meios rurais, perdendo cada vez mais líderes, sugados por um "rapto social", por uma espécie de panurbanismo, movimento que iria criar problema maior adiante, como ele dizia, referindo-se ao fenômeno do desenraizamento dos jovens recém-citadinos, para onde os levava o êxodo rural. (Santos, 2001)

Ademais, quando perguntamos à narradora, o que ela entende por quilombola, ela nos responde, nem posso dizer assim (sorrindo). O que ew entendo foi a melhora. Foi melhorando da noite pro dia. Para compreensão dessa questão buscou-se a contribuição de Hall (2011), pois esse expõe que: "as identidades [...] não são coisas com as quais nascemos, mas são formadas e transformadas no interior das representações [...]”. Logo, a partir do que foi exposto pela narradora sobre a comunidade de Nossa Senhora do Livramento, ficou subtendido que, após a transformação em comunidade quilombola, ou seja, após terem recebido a titulação e serem reconhecidos como remanescentes de quilombo pelo Estado, eles ainda assim não se reconhecem como tal.

Assim, nas sociedades contemporâneas as identidades estão sendo transformadas a cada momento, não existindo uma identidade única que o indivíduo levará pelo resto da vida, pois, as pessoas precisam tomar consciência que tanto a identidade quanto o pertencimento podem ser modificados a qualquer momento, na contemporaneidade. 
Sobre a análise das lembranças de dona Osmarina percebe-se que, mesmo em meio às mudanças ocorridas, eles ainda desenvolvem na comunidade o trabalho na lavoura, no junco e também na pesca, a minha mãe ficou trabathando na lavoura, nojunco, fícou eta e ourmão dela (pausa) á ela ía tirar ojunco, aú tinha a roca também, o peixe. Que nesse tempo era muito peixe aqui. Meu tio e ela ía pro río, ai eles botavam aquele "cacurí, sabe?! Aí quando eles chegavam lá chega tava balançando de peixe. Era muito peixe. Quando dava fé eles chegavam com o paneiro cheio. Nós não passava necessidade. Aí o papai quando era no final do més ele sempre mandava as coisas, quando ele tava pra lá...

Essa declaração acima evidencia as mudanças que estão ocorrendo não somente na comunidade estudada, mas também em várias comunidades tradicionais da Amazônia, causadas pelos efeitos da globalização. Foi percebido ainda pelo discurso da narradora que o rio desempenha um papel fundamental na vida dos moradores da referida comunidade. Porém, atualmente, vem sofrendo os efeitos da pesca predatória por parte de pessoas de fora da localidade.

Em relação aos aspectos culturais da comunidade, em meio à comunidade e suas mudanças ao longo do tempo, uma questão nos chamou bastante atenção, pois ao indagarmos a moradora sobre as brincadeiras e músicas de sua época, nos respondeu que nãa bríncava, apenas construía os brinquedos para os irmãos brincarem, pois nunca gostou de brincar. Eu desde nova não gostei de brincar. Negócio de jogo de baralho, casinha, boneca, também nunca goster. Aí eu fazia assim, eu mandava eles fazerem barraca no terreiro. Agora en fazia aqueles pratinhos de barro, panetinha, tudo de barro. Á eu dava feijão, dava arroz pra eles. Dizia: "tá aqui, levam lá pro barraco de vocês". Até hoje ainda, esse negócio de bríncadeira pra mim.. No tempo que ew era nova sabe, 
ninguém pisava no meu pé, eu era brava mesmo. Agora, depois que chega uma idade eu não sou mais assim não.

Percebe-se assim, certa indiferença no discurso da narradora ao se referir às brincadeiras e brinquedos de sua época. Talvez esse sentimento, inconscientemente, seja fruto das condições sociais em que viveu, pois desde cedo trabalhava e ainda tinha que cuidar dos irmãos mais novos. Esse fato é tecido pela narradora ao falar das facilidades de se ter brinquedos atualmente, uma vez que as crianças de hoje têm bonecas, porém, não valorizam. Nesse tempo não tinha boneca, que hoje em dia a gente vê boneca jogada por todo canto, né?! As criancas ganham brinquedos e não sabem usar. E nesse tempo eu fazia.. Então tinha o cacho de açi, a gente "depeta" o açai, aú fíca aquela cabecinha pra címa, né?! Aú ew agarrava e tirava aquelas pernas "tudinho" e deixava só dois assim, que era os braços. Aífazia as bonecas pra eles.

Eu não ía bríncar, mas fazia de tudo pra eles. Cachimbo de barro. Eu fazia aqueles cachimbos que era pra eles fumarem, que nesse tempo era tabaco de "mothe". Eu "migava" o tabaco, aí eu dava o tabaco. "Tá aqui, leva os tabaco". Eles enchiam os cachimbor de tabaco". Quando acabavam de almoçar, cada cá tinham sua cama de suador. Eu mesma fazia os suador, que era pra fazer as camas deles. Avi eles fícavam fumando até de noite. Quando a mamãe chegava perguntava "cadê os meninos?"Eu falava: "tão aútudo dormindo debaixo do barraco".

Nota-se ainda que os brinquedos e as brincadeiras construídas por dona Osmarina (em sua infância) estavam relacionados a sua realidade, ou seja, representavam o espaço, saberes e valores cultivados no pequeno povoado. Assim, a pequena Osmarina representava o papel de mãe das outras crianças (no caso de seus irmãos), algo bastante recorrente nas populações rurais, ou seja, ela representava nas 
brincadeiras com os irmãos, a própria realidade deles. Contudo, é importante destacar que dentre as brincadeiras relatadas, estava o hábito de fumar em cachimbo, algo bastante comum nas localidades interioranas. Hoje, impróprio para crianças e adolescentes, porém, naquele período parecia algo normal, tanto é que dona Osmarina nos relata esse fato com bastante naturalidade, ou seja, sem nenhum espanto.

Em relação à música foi diferente, dona Osmarina se mostrou bastante feliz ao relatar, como se estivesse revivendo aqueles momentos. Em relação a isso, Halbawachs (2003) nos assevera que: “a lembrança é uma imagem introduzida em outras imagens, uma imagem genérica transportada ao passado" (p. 93). Assim sendo, ao indagarmos sobre as músicas daquele período, ela nos respondeu que eram feitas pelos próprios moradores, eles que faziam. Tem um senhor ati, lá em cima, que toca carimbo; o sew Valdeci. Ele sabe as músicas. Sew Valdecir ainda tem até o tambor dele. Aú depois começow a aparecer som, todo mundo tem aí.. E tinha o carnaval. No tempo de nova, a gente se fantasiavare se juntava um monte de moça pra ir pular o carnaval. Era muita gente. A gente ía pro Terreirão. Não cheguemos a ir pra São Luiz, mas pro Terreirão a gente ía brincar o carnaval (pausa). Eu me fantasiava "tudinho" de homem, colocava um chapéuna cabeç, um guarda chuva do lado aqui. Não tinha quem me conhecesse (risos). As vezes ew deixava eles virem "tudinho" pro salão. Que nem lá em cima, no salaio do Panta, ai tinha aquele "bucado" de gente, quando dava fé eu buiava.. Guarda-chuva, óculos nos othos, chapéu na cabeca, de bota.

Não tinhaquem me conhecesse (risos).

Percebe-se no discurso acima, da moradora, que, apesar de ela rememorar alguns acontecimentos que marcaram sua vida, acaba reconstruindo algumas das identidades culturais da referida localidade, por meio da memória coletiva, de seu 
relato oral, onde nos informa que antes eles dançavam o carimbó, pulavam carnaval, brincavam, ou seja, se divertiam muito, porém depois apareceram as músicas eletrônicas.

Perguntamos ainda se ela poderia relatar como era a sua época de adolescente, como era a diversão naquela época, ah, eu namoreí com um trabathador da estrada de ferro, ai depois teve outro que trabathava também. A gente ia pra festa, o carimbo, uns tambó, fazia assim, era muito bonito o acompanhamento do carimbó. Tinha uns tambó que eles batia. Tinha frota, que eles faziam aquelas frotas. Era muito bonito (pausa). Se reunia todo mundo, passava a noite naquela brincadeira (pausa). Hoje em dia o pessoal, se vão pra uma festa, só dançam aquelas coisas... Mudou muito, num é do ritmo de antigamente, que a gente ía pra festa, se agarrava com o namorado aí (meu Deus do céw) risos. Mas agora, hoje em dia não, eles querem só beber, brigar

No discurso acima são percebidos alguns sentimentos, tais como: alegria e saudade. Pois nos relata sua época, dizendo que era muito diferente da atualidade (os namoros, as festas, as músicas, as pessoas etc.). Ou seja, está bastante mudado, pois segundo a moradora, hoje em dia o pessoal, se vão pra uma festa, só dancam aquelas coisas...e também, hoje em dia [...] eles querem [...] beber, brigar

Pode-se perceber nos relatos de dona Osmarina que atualmente os jovens moradores da comunidade não valorizam o carimbó como cultura, que a grande maioria não escuta e nem se preocupa com as letras das músicas, aliás, a diversão desses jovens se resume a bebida, brigas e a ouvir músicas eletrônicas, tecnobrega, melody, funk, forró, sertanejo, arroja, dentre outros ritmos.

Partindo do relato da moradora, percebe-se que esses jovens vivem num contexto de uma sociedade globalizada, onde cada vez mais é intenso o acesso às novas tecnologias e também aos novos ritmos musicais, divulgados pelos meios de 
comunicação. Em relação a essas questões sobre a globalização e as transformações das identidades culturais na vida social dos jovens, Hall vem afirmar que:

Quanto mais a vida social torna-se mediada pelo marketing global de estilos, lugares e imagens, pelos trânsitos internacionais, por imagens de mídias e sistemas de comunicações em redes globais, mais as identidades tornam-se descartáveis - desconetadas - de tempos, lugares, histórias e tradições específicas, parecendo estar à deriva (Hall, 1995: 57).

Atualmente os jovens têm acesso aos variados meios de comunicação, tais como: televisão, rádio, celular etc, sendo que o uso desses recursos tecnológicos, principalmente dos aparelhos celulares, cada vez mais sofisticados (com acesso à internet e às redes sociais), facilita que jovens e adolescentes baixem vários aplicativos (que darão a eles acesso a outros ritmos musicais), colaborando assim para a transformação das identidades culturais desses moradores, e como consequência, a desvalorizaçãoda cultura local, por parte deles. Assim, o carimbó, que anteriormente era cultivado como cultura popular da comunidade, perde espaço entre os jovens, principalmente nos locais em que eles frequentam, já que nesses locais a música é eletrônica e os ritmos são outros.

Portanto, de acordo com o que fora observado na comunidade e nas entrevistas realizadas com dona Osmarina (Neném), é relevante dizer que, apesar de alguns valores culturais da comunidade ser pouco preservados pela população local, ainda na agricultura, na pesca etc., permanecem inalterados, ou seja, sem o uso de qualquer tecnologia mais elaborada; ou no aspecto medicinal, onde o tratamento alternativo é feito com ervas medicinais.

\section{PARIÇÕES}

Walter Benjamin, em seu artigo "o narrador”, afirma que entre os que narram histórias, existem dois grupos de narradores anônimos: o viajado, e aquele que ganhou a vida sem sair do seu país, ou melhor, do seu lugar, porém, esse conhece as histórias e tradições de seu povo. Deste modo, "o senso prático é uma das características de muitos narradores natos", o que possibilita com isso, que entre narradores e ouvintes, ocorra a transmissão de informações e saberes de uma geração a outra. Com isso, observando, de certa forma, o que foi narrado.

Nosso objeto de estudo foi as narrativas da história de vida de dona Neném, com a perspectiva de entender como se deu o processo de rurbanização, comum nas 
comunidades tradicionais na contemporaneidade. A narradora se mostrou bastante contente em poder relatar fatos de sua vida e também sobre a comunidade, pois, como confirma Halbwachs (1968), uma pessoa idosa passa a desempenhar uma função social, que não pesa sobre os homens de outras idades: a função de lembrar, e lembrar bem.

Ao analisar as narrativas de dona Osmarina (Neném) chegou-se a seguinte conclusão: do importante papel que cumpre a memória na (re) construção identitária dos sujeitos e da própria comunidade, pois foi justamente por meio das narrativas orais da narradora que foi possível reconstruir imagens sobre a história da referida comunidade, ou seja, obtivemos informações de como era o povoado antes de ser transformado em comunidade, como era a cultura do local, bem como o processo de rurbanização.

\section{REFERÊNCIAS}

AMARAL, Assunção Jose Pureza. Caminhos negros e afrodescendência na Amazônia. Entre os rios e as florestas da Amazônia: perspectivas, memórias e narrativas de negros em movimento/ Marilu Marcia Campelo, Raimundo Jorge de Deus e Zélia Amador de Deus (org). Belém: UFPA, GEAM. 2014, p. 81-105.

BAUMAN, Zygmunt. Identidade: Entrevista a Benedetto Vecchi. - Rio de Janeiro: Jorge Zahar. Ed., 2005.

BENJAMIN, Walter. O narrador: considerações sobre a obra de Nikolai Leskov. Magia e técnica, arte e política: ensaios sobre literatura e história da cultura. São

Paulo: Brasiliense, 1994, p. 197-221.

BENTES, Nilma. Aspectos da trajetória da população negra no Pará. Belém: UFPA, GEAM. 2014, p. 75 - 83.

BOSI, Ecléa. Memória e Sociedade: Lembranças de Velhos- 3. Ed. - São Paulo: Companhia das Letras, 1994.

BRASIL, 2007. Decreto $n^{\circ}$ 6.040. Institui a Politica Nacional de Desenvolvimento Sustentável dos Povos e Comunidades Tradicionais.

FERREIRA, Jerusa Pires. Armadilhas da Memória e outros ensaios. Cotia, SP: Ateliê Editorial, 2003.

FREIRE, Gylberto. Da Ecologia à Rurbanização: Considerações Gerais um Tanto 
Desordenadas (1982). In: Rurbanização: Que é? Recife: Massangana, 1982.

HALBWACHS, Maurice. A Memória Coletiva. - 2. Ed. PressesUniversitaires de France Paris, França, 1968.

HALL, Stuart. A Identidade Cultural na Pós-Modernidade. - Ed. 11. Rio de Janeiro:

DP\&A, 2011. A Questão da Identidade Cultural. Textos Didáticos, Campinas - São Paulo:

IFCH-Unicamp, 1995

POLLAK, Michael. Memória, Esquecimento, Silêncio. Estudos Históricos. Rio de Janeiro, vol. 2, n. 3, 1989, p. 3-15.

SANTOS, Raimundo. Rurbanização e revolução agrária em dois registros clássicos.

Estudos Sociedade e Agricultura, 2001.

Disponível em:

http://biblioteca.clacso.edu.ar/ar/libros/brasil/cpda/estudos/dezesseis/rai16.htm

Acesso: 11abr20.

SILVA, Tomaz Tadeu da.Identidade e diferença: a perspectiva dos estudos culturais / Tomaz Tadeu da Silva (org). Stuart Hall, Kathryn Woodward. 15. Ed. - Petrópolis, RJ: Vozes, 2014.

TEIXEIRA, Marco Antônio Domingues. Comunidades de remanescentes de Quilombo de Pedras Negras do Guaporé: Bases para a discussão sobre a regularização fundiária. In Entre os rios e as florestas da Amazônia: perspectivas, memórias e narrativas de negros em movimento/ Marilu Marcia Campelo, Raimundo Jorge de Deus e Zélia Amador de Deus (org). Belém: UFPA, GEAM. 2014, p. 237272.

Recebido: $31 / 05 / 2020$

Aprovado: 04/09/2020 